Ewa Rajewska

Tłumaczki chleb powszedni. Ludmiła Marjańska i Mary Swann ${ }^{1}$

\author{
Wistawa obiera kartofle \\ Urszula zbiera dereń \\ Ewa urzęduje Am Gestade [... ]. \\ Julia Hartwig, Uciekając od swoich zadań
}

Daty urodzin kanadyjskiej poetki Mary Swann i jej polskiej tłumaczki Ludmiły Marjańskiej dzieli niespełna dziesięć lat (są to odpowiednio lata: 1915 i 1923), nieodległe są również daty ich poetyckich debiutów (1966 i 1958 rok). Obie wypada uznać za poetki niedostatecznie jeszcze opisane, osobne, niemainstreamowe - także ze względu na ich przywiązanie do dość tradycyjnej, wyrównanej metrycznie i rymowanej formy wierszowej. Swann i Marjańską łączy wrażliwość na piękno przyrody i poszanowanie dla - zwłaszcza kobiecej - codzienności; bardzo ważnym budulcem twórczości każdej z nich było doświadczenie życiowe. Na tym jednak podobieństwa się kończą. Mary Swann to niemal pozbawiona wykształcenia gospodyni domowa, która większą część życia spędziła na odludnej farmie w prowincji Ontario, opublikowawszy tylko kilka wierszy w prasie lokalnej; Ludmiła Marjańska natomiast to kochająca podróże mieszkanka środkowoeuropejskiej metropolii, która w wieku dojrzałym zdobyła uznanie krytyki literackiej, oprócz poezji i prozy własnej publikowała wysoko

1 Artykuł został napisany w ramach badań finansowanych ze środków Narodowego Centrum Nauki (projekt badawczy nr 2015/17/B/HS2/01245). 
oceniane tłumaczenia poetek i poetów języka angielskiego: Emily Dickinson, Elizabeth Barrett Browning, Williama Butlera Yeatsa, Marianne Moore, Theodore'a Roethke, Richarda Wilbura i innych; brała czynny udział w życiu literackim, a nawet - jako prezeska Stowarzyszenia Pisarzy Polskich w latach 1993-1996 - należała do literackiego establishmentu.

Największą różnicą między Swann i Marjańską jest jednak to, że Mary Swann nigdy nie istniała. Była, podobnie jak jej poezja, tylko literackim konstruktem - bohaterką powieści, która opowiada właśnie o konstruowania mitu genialnej a zapoznanej poetki przez osoby zajmujące się profesjonalnie literaturą: począwszy od wydawcy, przez grono literaturoznawców akademickich, w tym oficjalnego biografa, po pracownicę prowincjonalnej biblioteki i regionalnego muzeum z lokalną „izbą pamięci”.

Opublikowana w 1987 roku powieść autorstwa wielokrotnie nagradzanej, w tym także Pulitzerem, pisarki kanadyjskiej Carol Shields, zatytułowana Swann. A Mystery, trzy lata później pozbawiona podtytułu i odtąd wydawana po prostu jako Swann, w polskim przekładzie Marjańskiej ukazała się w roku 1998 jako Zagadka wiecznego pióra. Już tytuł wskazuje na przesunięcia dokonane w tłumaczeniu. Ten oryginalny: Swann, nawet nie: „Mary Swann”, zdaje się zapowiadać biografię - i tej obietnicy nie spełnia, ponieważ historię życia nieistniejącej poetki czytelnik musi sobie skonstruować sam w trakcie lektury czterech opowieści, których bohaterami są kolejno: młoda ginokrytyczka - odkrywczyni twórczości nieżyjącej już Swann dla literaturoznawczego świata, wypalony zawodowo biograf-mizogin, lekko zdziwaczała małomiasteczkowa bibliotekarka, która wypożyczała poetce książki, oraz erudycyjny wydawca-amator, właściciel prowincjonalnej oficyny drukującej nową poezję kanadyjską.

Każde z nich - badaczka, biograf, bibliotekarka i wydawca zna dobrze wiersze Swann i ma swoje ulubione utwory, które - co chyba najciekawsze - zostają w powieści przytoczone in extenso; każde $\mathrm{z}$ nich ma też swój udział w konstruowaniu jej mitu. Badaczka zaciera ślady po należącym do Swann słowniku rymów i zwleka z publikacją jej dziennika, który okazał się dla niej wielkim rozczarowaniem: 
Wciąż nie mogę się zdecydować, jak przedstawić notatnik na sympozjum: czy jako zwykły wiejski dziennik („Swann jedną nogą tkwiła mocno w świecie codziennych zajęć, a drugą ...”), czy też jako kryptogram spisany przez kobietę, która wpadła w panikę, gdy uświadomiła sobie, że jest artystką. [Shields 1998: 52]

Biograf $\mathrm{z}$ braku interesującego materiału zaczyna konfabulować; „Jest bardzo prawdopodobne, że Swann czytała w tym okresie Jane Austen, ponieważ...” [Shields 1998: 123] - pisze, planując także poświęcić w swojej książce miejsce na przedstawienie wplywu poezji Emily Dickinson na twórczość Swann, chociaż po rozmowie z bibliotekarką wie, że bohaterka jego biografii czytywała wyłącznie niezbyt ambitne powieści popularne, a szczególną estymą darzyła Ednę Ferber. Bibliotekarka wyolbrzymia swoją znajomość z poetką, kreując się niemalże na jej powiernicę, a odtworzona przez nią $\mathrm{w}$ muzeum regionalnym sala pamięci Mary Swann, rzekomo autentyczna kuchnia, w której Swann pisała, to czysta fikcja, Swannowie żyli w nędzy; bibliotekarka, odwiedziwszy ich dom, by przejąć do muzeum przedmioty osobiste pozostałe po poetce, nie mogła uwierzyć, że „[t]o jest wszystko. Tak było" [Shields 1998: 168]. Największej mistyfikacji dopuszcza się jednak wydawca, któremu poetka powierzyła swoje rękopisy: do torby pełnej świstków papieru - trudno tu nie pomyśleć o kuferku Emily Dickinson - jego nieświadoma niczego żona wyrzuca wnętrzności sprawionej na obiad ryby i mniej więcej połowa wierszy zapisanych zmywalnym atramentem staje się nieczytelna.

Do północy dokonali transkrypcji więcej niż pięćdziesięciu utworów. Ostrożni na początku, stopniowo nabierali śmiałości, a w pracy podtrzymywała ich świadomość, że będą mogli sprawdzić manuskrypt z panią Swann, która na pewno pamięta, jak brzmiały zamazane słowa. [...] Bardziej martwily ich wiersze, które uległy znaczniejszym uszkodzeniom. [...] Łamali sobie głowy i naradzali się nad każdym kleksem, potem odgadywali słowa, wreszcie wymyślali je. Późna godzina, 
morze czarnej kawy, intensywne suche gorąco w pokoju udzieliły im nierozważnego pozwolenia. W jakimś punkcie Hilda, dostosowując brakujące wersy, a nawet znaczniejszą część brakującej strofy, powiedziała, że wyczuwa, co kryje się w głowie Mary Swann. Ma wrażenie, że zamieszkała w ciele innej kobiety. [Shields 1998: 229-230]

Tytuł przekładu Ludmiły Marjańskiej - Zagadka wiecznego pióra - zamiast biograficznego eksponuje wątek sensacyjny. Najbardziej zagadkową pamiątką, jaka pozostała po Mary Swann, było jej wieczne pióro, parker nr 51, jedyny wartościowy - w kontekście skrajnego ubóstwa, w jakim żyła, można powiedzieć nawet: zbytkowny - przedmiot, jaki posiadała. Swann nie miała własnych pieniędzy, nie miała też przyjaciół - od kogo więc dostała pióro? Od męża, przed którym ukrywała wiersze pod kuchennym linoleum; który racjonował jej nawet książki wypożyczane z biblioteki, a gdy odważyła się pojechać na rozmowę z wydawcą, po powrocie ją zakatował?

Inną zagadką powieści jest systematyczne znikanie przedmiotów należących do poetki: jej pamiętnika, nielicznych zachowanych egzemplarzy jej tomiku (nakład liczył ich tylko 200), rękopisów, fotografii, a nawet prywatnych notatek badaczy pracujących nad jej twórczością. Ta systematyczność wskazuje na zaplanowane działanie - między wierszami, czy może raczej: didaskaliami ostatniej, piątej części powieści, która ma formę scenopisu i tytuł The Swann Symposium [Sympozjum poświęcone Mary Swann], wyczytujemy, że pamiątki po Swann giną na zlecenie pewnego poważanego literaturoznawcy, który przez podstawionego człowieka kupuje nawet jej zrujnowaną farmę. Zgromadziwszy wszystkie związane z poetką przedmioty, zyska, jak się domyślamy, jeszcze większe możliwości manipulacji faktami i wyłączność na zarządzanie artefaktem, będzie miał monopol na kreowanie mitu powieść nie pozostawia wątpliwości, że ten monopol będzie się wiązał z monopolem na zyski. Przekład Marjańskiej za sprawą tytułu przesuwa punkt ciężkości w stronę tego wątku.

„Mieszając makabryczny realizm z surrealistycznym, postmodernistycznym sposobem kreowania poezji, interpretowania jej, 
dowartościowywania i lansowania jako sztuki, Swann jest spektakularnym osiągnięciem” - pisała Elaine Showalter [2015: 112]. Przekład powieści o konstruowaniu literackiego mitu to także konstrukcja. A Marjańska konstruowała swoją Swann dość mozolnie.

Pracując nad przekładem Swann, pisała w liście do zaprzyjaźnionego poety, że to thumaczenie robione „dla chleba”, że zabiera jej czas, który, jak sobie obiecywała, będzie „dla wierszy i własnych lektur"

Skądinąd dobry chleb bardzo lubiła. Zaświadcza o tym choćby dedykowany jej wiersz Tadeusza Gicgiera - stylizowana pamiątka, dworny komplement:

\section{Ludmile Marjańskiej}

Łakoma dziejów dawnych, znużona dziejami współczesnymi przybyłaś, pani, do Supraśla; wędrowaliśmy ulicami miasteczka wśród domów i ogrodów, gdzie słońce północy pali się w pelargoniach i w kwiatach nasturcji, a dogasając, jeszcze płonie w kroplach żywicy na schnących bierwionach; wtedy delikatnymi zmysłami poetki wyłowiłaś zapach starej piekarni, tak inny od zapachu bazyliańskich murów, ksiąg murszejących, które były niegdyś pokarmem dla ducha i oto niesiesz na liściu dłoni chleb ciepły, zdjęty z klonowego liścia, to są twoje dożynki, chleb niesiony godnie, kołacz rumiany, spękany jak kora.

[Chleb z Supraśla, Gicgier 1989: 19] 
Ten bochen chleba przywieziony z Supraśla powraca w wierszu Marjańskiej Światło z tomu Prześwit (1994). Ciepły, tradycyjnie wypieczony chleb, ów „pokarm dla ciała”, ustawiony przez Gicgiera w kontrze do „ksiąg murszejących”, można potraktować synekdochicznie. Marjańska istotnie była łakoma - życia, we wszystkich jego zmysłowych przejawach. Zdawałoby się, że plasuje to poezję - pokarm dla ducha na straconej pozycji, lecz $\mathrm{w}$ autotematycznym utworze zatytułowanym po prostu Wiersze czytamy: „Życie zawsze było ważniejsze / od wierszy. [... ] / Gasły rymy, fałszywie / pobrzmiewały jamby, / trocheje, anapesty traciły znaczenie, / zapach chleba zwyciężał. // A jednak -” [Marjańska 1996: 19]. Twórczość poetycką Marjańskiej aż po tomy ostatnie, nie wyłączając epicedialnej $\dot{Z} y w i c y$, cechuje zachłanny witalizm.

Marjańska, poetka i tłumaczka poezji wysokiej, zawiedziona prozaiczka, redaktorka Programu III Polskiego Radia, w interesującym nas momencie już od kilkunastu lat na emeryturze, czasem decydowała się przetłumaczyć powieść popularną „dla chleba”. Tym razem na zamówienie dużego wydawnictwa będącego częścią międzynarodowego koncernu medialnego na warsztacie miała powieść naprawdę niebanalną. I nie tak całkiem oderwaną od jej literackich zainteresowań. Zwłaszcza tłumaczenie zamieszczonych w Swann wierszy wzorowanych na dykcji poetyckiej Dickinson musiało być dla niej ciekawym kontrapunktem. Nad przekładami z Dickinson pracowała już wówczas od ponad trzydziestu lat; jej pierwsze tłumaczenia ukazały się w prasie literackiej w 1964 roku, lecz z wydaniem osobnego tomu przekładów ubiegli ją najpierw Kazimiera Iłłakowiczówna, a potem Stanisław Barańczak; tom I jestem róża wyszedł dopiero w 1998 roku, a Przeczucie - w 2005, już po śmierci Marjańskiej. Obcowanie z poezją Dickinson było tak długotrwałe i tak bliskie, że na marginesie rękopisu jednego z wierszy Marjańskiej z połowy lat 9o. widnieje zaniepokojony dopisek „porównać z Emily!”3.

3 Fragment wiersza, przy którym widnieje ten dopisek, brzmi: „Nie miałam czasu na szczęście / zajęta byłam miłością / a to nie zawsze jest w zgodzie" - i rzeczywiście odrobinę przypomina przekształcony koncept z 478 (I had no time to Hate) 
Przekłady wierszy Mary Swann, bardzo sprawnie napisanych w stylistyce pastiszującej twórczość poetycką Dickinson i Christiny Rossetti przez autorkę powieści - Carol Shields, są translatorsko najciekawszym zagadnieniem Zagadki wiecznego pióra. Były nie lada wyzwaniem: efekt musiał być intrygujący, a zarazem miejscami miał sprawiać wrażenie puszczonego, tak aby badaczka feministyczna, w oryginale Shields przedstawiona wprawdzie nie bez ironii (zdrady na samej sobie), ale jednak faworyzowana jako jedyna z czworga protagonistów ma do swej dyspozycji narrację pierwszoosobową - mogła powiedzieć wiarygodnie:

Biedna Mary Swann. Tak właśnie o niej myślę: biedna Mary Swann, ze swoim mistycznym słuchem wyczulonym na melodię słów, okradziona z życia, okradziona z uznania. [... ] żaden ze współczesnych uczonych nie wie, co robić z jej rymami, z jej strasznymi: gaj/maj czy wrzesień/jesień [oryg. „moon/June”, „September/remember”]. Przyprawia ich to o ból głowy i powoduje, że prychają przez nos. „Co można zrobić - powiadają - z tą wiejską dojarką w wiktoriańskich aksamitach?”

Robię się niesforna i napastliwa, kiedy mowa o tych cholernych rymach. $\mathrm{Z}$ wyjątkiem najgorszych brzękadeł [notabene śliczny ekwiwalent oryginalnych „clinkers” - E.R.] (wiry/ kiry) [„giver/liver”] nie wydają mi się bardziej natrętne niż przytupywanie nogą do taktu czy dźwięk dzwonka w oddali. Zresztą linijki wiersza pędzą kłusem przed siebie za szybko, żeby przywiązywać zbytnią wagę do rymów. Jest w nich jakaś pracowita dbałość o dobre maniery. [Shields 1998: 17]

Swann miała być przy tym „profound without being brillant” [Shields 1996: 42], według Marjańskiej: miała „mieć głębię i nie być olśniewająca" [Shields 1998: 40]. Ponadto przekłady jej wierszy musiały być otwarte - jak oryginały - nie tylko na różne interpretacje, musiały też uwzględniać różne warianty wyjściowego tekstu. Tak dzieje się na przykład w poniższym wierszu:

Dickinson. Brulion zatytułowany 1995/1996 wiersze od sierpnia 95 znajduje się w zbiorach Archiwum Ludmily Marjańskiej w Sandomierzu. 
Blood pronounces my name

Blisters the day with shame

Spends what little I own,

Robbing the hour, rubbing the bone.

[Shields 1996: 57]

[próba przekładu filologicznego]

Krew wymawia moje imię

Pokrywa dzień pęcherzykami hańby

Zużywa to niewiele, co posiadam

Okradając godzinę, trąc/polerując kość.

W tłumaczeniu Marjańskiej:

Krew po imieniu mnie nazywa

Pęcherzem wstydu dzień okrywa

Marnuje to czego mam mało,

Zabiera czas i ściera ciało.

[Shields 1998: 52]

Badaczka feministyczna nie ma wątpliwości, o czym jest ten utwór:

jednego jestem pewna: wiersze Mary pełne są ukrytych aluzji do matki, do siły i gwałtowności rodzinnych więzów. [...] [Ten - E.R.] wiersz wskazuje na nieuniknioną trwałość więzów krwi, a szczególnie tych, które łączą matki z córkami. [... ] prześladuje [mnie - E.R.], śpiewa głośno w mojej głowie i bębni w sam środek mojego serca. [Shields 1998: 52]

Swoją wizję ma biograf, który w rozmowie z bibliotekarką oświadcza: „oczywiście pani może się z tym nie zgodzić - ale dla mnie to się bezpośrednio odnosi do sakramentu komunii świętej. A być może, i to jest moja teza, może jeszcze bardziej do żywiołowego przymierza krwi, zjadania boskiej głowy, i tego rodzaju rzeczy” [Shields 1998: 153]; notabene „more elemental sort of 
blood covenant, eating the Godhead" [Shields 1996: 185] to raczej „bardziej pierwotny rodzaj przymierza krwi, spożywania bóstwa”, Marjańska-tłumaczka nie jest tutaj zbyt dokładna. Wróćmy jednak do rozmowy biograf - bibliotekarka:

- Widzi pani, krew jest symbolem. Przedstawia kontinuum wierzeń, metafizyczne przymierze z niewytłumaczalnym wszechświatem.

Rose milczała $[\ldots]$. Nie była zresztą w stanie wymówić słowa: menstruacja. Wolałaby umrzeć. [...]

- Ale widzi pan - zaczęła - pani Swann była kobietą i ... [...]. Nie, to nieważne. [Shields 1998: 153-155]

W przedostatnim rozdziale dowiadujemy się, że utwór o krwi jest w dużej mierze dziełem wydawcy i jego żony, niespełnionej poetki i miłośniczki Rilkego:

Ostatni wiersz, najbardziej uszkodzony, zaczynał się od słów: „Krew po imieniu mnie nazywa”. A może to było: „Krew mnie imieniem złym wyzywa”? [w oryginale „Blood pronounces/ renounces my name", Shields 1996: 282]. Drugą linijkę można było odczytać na dwa sposoby: „Promieniem wstydu dzień okrywa” albo „Pęcherzem wstydu dzień okrywa” [„Brightens / blisters the day with shame"]. Zdecydowali się na słowo „pęcherzem”. Trzecia linijka: „Marnuje to, czego mam mało”, mogło równie dobrze być odczytane jako: „Związuje to, czego mam mało" [„Spends/bends what little I own”], ale napisali „marnuje”, ponieważ - mimo iż tego nie powiedzieli - bardziej im się podobało. [Shields 1998: 230]

Wyraźne skojarzenia z liryką Dickinson budzi utwór Swann/ Shields posługujący się sugestywną metaforyką pustych - opustoszałych, ogołoconych - pomieszczeń jako obrazu stanu psychicznego. Nie są to jednak pokoje zwykłego domu, lecz pokoje mózgu. Niezwykle oszczędne cztery wersy nie mówią wprost o wyjaławiającym poczuciu zagrożenia, o nagim strachu; dopiero zakończenie ostatniej linijki napomyka o kryjówce: 
The rooms in my head are bare Thunder brushes my hair The mirror on the other side Opens the place where I hide. [Shields 1996: 170-171]

[próba przekładu filologicznego]

Pokoje w mojej głowie są nagie Grzmot czesze moje włosy Lustro po drugiej stronie Zdradza miejsce, w którym się ukrywam.

Koncept umysłu jako zespołu pomieszczeń znamy z liryku Dickinson o szczególnym nawiedzeniu ${ }^{4}$ :

One need not be a Chamber - to be Haunted, One need not be a House The Brain has Corridors - surpassing Material Place - [...].

[Dickinson 1975: 333]

W przekładzie Marjańskiej:

Nie tylko w komnatach straszy Nie trzeba wcale być gmachem Korytarze w mózgu mogą większym

Niż realne napawać strachem $[\ldots]$. [679, Dickinson 2013: 74]

Także w słynnym utworze Dickinson o umyśle doświadczającym własnej śmierci mózg jest przedstawiony jako pomieszczenie:

I felt a Funeral, in my Brain

And Mourners to and fro pisała Elżbieta Tabakowska [2001: 149-159]. 
Kept treading - treading - till it seemed

That Sense was breaking through $-[\ldots]$.

[Dickinson 1975: 128]

W przekładzie Marjańskiej:

Czułam, szedł pogrzeb w moim mózgu,

Żałobnicy, tu i tam krocząc,

Stąpali ciężko - coraz ciężej -

Aż rozum wyrywać się począ - [...].

[280, Dickinson 2013: 34]

Tłumaczenie liryku Swann/Shields o pustych pomieszczeniach wewnątrz głowy pod piórem Marjańskiej przyjęło taką formę:

W mojej głowie pusty dom

Moje włosy czesze grom.

Lustro po drugiej stronie

Otwiera miejsce, gdzie się chronię.

[Shields 1998: 142]

Opustoszałe, ogołocone, nagie pokoje [„bare rooms”] Swann/ Shields w tłumaczeniu Marjańskiej łączą się w przynajmniej z pozoru przyjaźniejszą całość - „pusty dom”. Na tę decyzję translatorską zapewne wpływ miał dokładny rym męski „dom - grom”, mający odwzorowywać oryginalny „bare - hair”. Jednak sympatykom twórczości Marjańskiej ten właśnie rym i pusty, martwy (?) dom mogą nasuwać skojarzenia z jej poezją oryginalną. We wcześniejszym o ponad dwie dekady, przejmującym liryku Marjańskiej o martwej królowej w martwym domu również można się dopatrzyć obrazu stanu psychicznego:

Martwa królowa w martwym domu czystym i jasnym i przewiewnym 
Uderz w stół

nie odezwie się nic

Uderz w pierś

moja wina i śmierć

Nie odpukuj w malowane szkło

nie dobijaj się do drzewnych drzwi

Wyniesiono królowę i tron

martwe szkło martwe drzwi

martwy dom

Uderz w dzwon.

[Marjańska 1977: 64]

Ale obok liryków świetnych i świetnie przełożonych w Zagadce wiecznego pióra znajdujemy także słabsze - i przełożone słabiej. Erudycja i gust trojga protagonistów-literaturoznawców dystansują upodobania lekturowe prowincjonalnej bibliotekarki. Najlepiej zapamiętane przez nią wiersze Swann, przytoczone w jej poświęconym fragmencie narracji, nie są tak wyrafinowane a w przekładzie Marjańskiej dodatkowo nie stronią od dopowiedzeń i „brzękadeł”. Najsłabszy jest chyba dwuwiersz:

A pound of joy weighs more

When grief had gone before

[Shields 1996: 215]

[próba przekładu filologicznego]

Funt radości waży więcej

Gdy wcześniej odszedł smutek.

W tłumaczeniu Marjańskiej za sprawą dopowiedzenia ciągniętego na siłę do dokładnego, żeńskiego i niewyszukanego rymu smutek traci swój niezależny status, z fenomenu staje się symptomem: 
Funt radości więcej waży

Gdy przedtem smutek nie znikał z twarzy.

[Shields 1996: 177]

I ten wiersz Swann/Shields przywodzi na myśl (zbanalizowaną) wersję utworu Dickinson oznaczonego numerem 135 (Water, is taught by thirst). U Dickinson doceniamy wartość, doświadczając jej braku, dokładniej zaś: jej utraty; u Swann wartość radości jest większa, gdy poprzedza ją jej antyteza.

Water, is taught by thirst.

Land - by the Oceans passed.

Transport - by throe -

Peace - by its battles told -

Love, by Memorial Mold -

Birds, by the Snow.

[135, Dickinson 1975: 63]

W tłumaczeniu Marjańskiej:

Wody nas uczy pragnienie.

Lądu - morskie przestrzenie.

Uniesień - bólu wiek -

Pokoju - opowieść o bitwach -

Miłości - nadgrobna modlitwa -

A ptaków - śnieg.

[Dickinson 2013: 23]

Ten liryk kieruje mnie z powrotem w stronę chleba, którego uczy głód. Dość wczesny wiersz Marjańskiej operuje bowiem konceptem podobnym do tego z przywoływanego utworu Dickinson; chleb okazuje się u Marjańskiej bardzo pojemnym członem porównania:

To jest tak mało:

rosną w naszym głodzie

przyjaźnie, miłość, szczęście, dom,

a suche liście przysypują wciąż 
pojęcia-gruzy.

Spod cierpliwych rąk

umyka kształt radości, głód

zostaje niezmieniony, tylko sen

przynosi czasem

przysmak przyjaźni,

miłość nasyconą.

A przecież gdzieś jest

spełnienie, szczęście, sytość,

pod drzewami

w przesianym słońcu stoły zastawione

i gęste wino, rozmowy i śmiech,

i dobroduszność, na co dzień wzgardzona,

jak biały, dobrze wypieczony chleb.

[Chleb, Marjańska 1977: 46]

Praca tłumaczki cudzej prozy była dla Marjańskiej ciężkim kawałkiem chleba - i był to panis cotidianus, który nie uległ przeistoczeniu w panis supersubstantialis - choć widać to najwyraźniej dopiero w momencie konfrontowania jej przekładu z oryginałem. Wtedy się okazuje, że tłumaczce zdarzały się błędy - niektóre popełniane zapewne przez nieuwagę (tytułem przykładu, pierwsze małżeństwo ginokrytyczki trwało nie trzy lata, lecz trzy miesiące), inne przez niezrozumienie, na przykład żargonu krytyki feministycznej (,to hell with the male power structure and to hell with penetration as sexual expression" [Shields 1996: 38 ] - to jednak nie: „niech diabli porwą siłę męskiej konstrukcji i do diabła z penetracją jako określeniem seksualnym” [Shields 1998: 37], chodzi raczej o potępienie patriarchalnej struktury władzy oraz penetracji jako jedynej możliwej manifestacji erotyzmu). Przesunięcia w przekładzie dotyczą też całości wyższego rzędu, takich jak konstrukcja postaci. Ta sama badaczka feministyczna w chwili introspekcji określa się jako „too flip”, a więc zbyt nonszalancka, impertynencka, zuchwała. Marjańska tłumaczy: „postrzelona”, tym samym upupia trochę swoją bohaterkę.

Zagadka wiecznego pióra stanowi kłopot dla krytyka przekładu. Oczywiście zawsze można powiedzieć, że duże wydawnictwo 
będące częścią międzynarodowego koncernu medialnego powinno było zadbać o rzetelną redakcję tłumaczenia. Nie unieważnia to jednak pytania o to, ile błędów dyskwalifikuje przekład i czy jego ogólna płynność oraz ciekawe tłumaczenia włączonych do niego utworów poetyckich mogą te błędy zrekompensować. Błąd $\mathrm{z}$ trzema miesiącami zamienionymi na trzy lata Joanna DybiecGajer nazwałaby „błędem krytycznym”, a dla tych przywoływany przez nią translatolog Mark Williams nie miał litości:

trzy akapity wybitnego tłumaczenia zawierającego mistrzowskie sformułowania i interpretacje nie mogą zrównoważyć jednego błędu krytycznego, tak jak ekscytujący wygląd nowego samochodu nie zrobi z niego akceptowalnego produktu, jeśli nie działają hamulce. [Dybiec-Gajer 2013: 187]

Rozumiem ten punkt widzenia, mimo wszystko nie jestem przekonana co do zasadności tego porównania.

W przełożonym przez Marjańską monodramie Williama Luce’a Piękność z Amherst (1981) jego protagonistka Emily Dickinson słynęła nie tylko z ekstrawaganckiej mizantropii, lecz także z fantastycznych wypieków („Keks: dwa funty mąki, dwa funty cukru, dwa funty masła, dziewiętnaście jajek, pięć funtów rodzynek, półtora funta porzeczek, półtora funta cytryn, pół kwarty koniaku - nigdy jednak nie biorę najlepszego koniaku ojca - pół kwarty melasy [...]. Wszyscy za tym keksem wprost przepadają. Mam nadzieję, że i państwu będzie smakował. [... ] Czasami robię keks dla jakiejś sąsiadki i załączam króciutką karteczkę, przeważnie tak okropnie mętną... (z uciecha $)$... że nikt jej nie może zrozumieć! Podobno w miasteczku zaczynają już zbierać moje karteczki. Ludzie porównują je, żeby zobaczyć, kto dostał najdziwniejszą” [Luce 1981: 51]). A według bohaterek powieści The Secret Life of Emily Dickinson Jerome’a Charyna [2010], współseminarzystek z Mount Holyoke, Dickinson nawet zwykły chleb potrafiła zmienić w wyrafinowane pieczywo, wręcz ciasto. Ale Dickinson Luce’a i Charyna, podobnie jak Swann Shields, była przecież tylko konstruktem. 


\section{Bibliografia}

Charyn Jerome (2010), The Secret Life of Emily Dickinson. A Novel, W.W. Norton \& Company, New York.

Dickinson Emily (1975), The Complete Poems of Emily Dickinson, red.

Thomas H. Johnson, Faber and Faber Ltd, London.

Dickinson Emily (1998), I jestem różą. Wybór wierszy, przeł. Ludmiła

Marjańska, Wydawnictwo Książkowe Twój Styl, Warszawa.

Dickinson Emily (2005), Przeczucie. Ostatnie przekłady Ludmity

Marjańskiej, Biblioteka Telgte, Poznań.

Dickinson Emily (2013), Poezje, przeł. Ludmiła Marjańska, C\&T, Toruń.

Dybiec-Gajer Joanna (2013), Zmierzyć przekład? Z metodologii oceniania $w$ dydaktyce przekładu pisemnego, wUJ, Kraków.

Gicgier Tadeusz (1989), Mój drugi dom, Krajowa Agencja Wydawnicza, Białystok.

Hartwig Julia (1999), Zobaczone, Wydawnictwo as, Kraków.

Luce William (1981), Piękność z Amherst, przeł. Ludmiła Marjańska, „Dialog”, nr 11, s. 17-19.

Marjańska Ludmiła (1977), Druga podróż, PIW, Warszawa.

Marjańska Ludmiła (1994), Prześwit, nakładem autorki, Oficyna

Wydawnicza Jędrzejów, Warszawa.

Marjańska Ludmiła (1996), Wiersze, „Pogranicza”, nr 2.

Shields Carol (1996), Swann, Vintage Canada, Toronto.

Shields Carol (1998), Zagadka wiecznego pióra, przeł. Ludmiła Marjańska, Świat Książki, Warszawa.

Showalter Elaine (2015), Wydziałowe wieże. Powieść akademicka i jej źródła (cierpień), przeł. zespół tłumaczy ze specjalności przekładowej IFP UAM w Poznaniu, red. Ewa Kraskowska, Ewa Rajewska, Wydawnictwo „Poznańskie Studia Polonistyczne”, Poznań.

Tabakowska Elżbieta (2001), Metafora: schemat wyobrażeniowy POJEMNIKA, w: tejże, Językoznawstwo kognitywne a poetyka przekładu, przeł. Agnieszka Pokojska, Universitas, Kraków, s. 149-159.

Ewa Rajewska

\section{Translator's daily bread. Ludmiła Marjańska and Mary Swann}

The article discusses a translation of a Carol Shields's novel Swann. A Mystery (1987) by a Polish poet Ludmiła Marjańska (Zagadka wiecznego pióra, 1998). Marjańska's translation is not an easy one to assess: it contains some shifts as well as simple mistakes, but Polish versions of lyrics quoted in the novel as written by a mysterious, unacknowledged (and non-existing) 
poet Mary Swann are undeniably its strongest point. What makes them more interesting, they show close affinity to poems by Emily Dickinson translated by Marjańska - and to her own poetry.

Keywords: literary translation; poetry; Ludmiła Marjańska; Emily Dickinson; Carol Shields; Swann. A Mystery.

Ewa Rajewska - dr hab., literaturoznawczyni, translatolożka i tłumaczka, adiunkt w Zakładzie Literatury xx Wieku, Teorii Literatury i Sztuki Przekładu Instytutu Filologii Polskiej UAM w Poznaniu, kierowniczka specjalności przekładowej na studiach magisterskich (www.przekladowa.amu. edu.pl). Opublikowała m.in. Dwie wiktoriańskie chwile w Troi, trzy strategie translatorskie. "Alice's Adventures in Wonderland" $i$ "Through the Looking Glass" Lewisa Carrolla w przekładach Macieja Stomczyńskiego, Roberta Stillera i Jolanty Kozak (2004), Stanistaw Barańczak - poeta i tłumacz (2007), Domyst portretu. O twórczości oryginalnej i przekładowej Ludmiły Marjańskiej (2016). Adres elektroniczny: rajewska@amu.edu.pl 
